\title{
CUSTOMER DISCOVERY OF BIOFERTILIZER BUSINESS (A LESSON FROM PT PHN EXPERIENCE)
}

\author{
Yeni Marlina*)1, Idqan Fahmi*), and Arif Satria**) \\ *) School of Business, Bogor Agricultural University \\ Pajajaran Street, Bogor 16151 \\ ${ }^{* *}$ Department of Community Development and Communication Sciences, Faculty of Human Ecology, \\ Bogor Agricultural University \\ Kamper Street, Dramaga Campus IPB 16680
}

\begin{abstract}
Demand for agricultural products in Indonesia increases in response to Indonesia's high population growth. With more limited agricultural land, agricultural productivity can be increased by the addition of fertilizer. Biofertilizer is currently popular fertilizer and can become a solution to increase productivity of agricultural products in limited land. PT PHN is a new company established in 2015 and produces biofertilizer under the brand XYZ . This research was conducted to analyze consumer perception of biofertilizer and XYZ fertilizer. The company tries to understand customer's problems and provides solutions with customer development model (CDM) method. Understanding and solution to the problem were then used as revision of the company's business model with business model canvas (BMC) approach. Primary and secondary data were used in this research. Primary data were obtained by observation and interview using several respondents. Secondary data were obtained from PT PHN staffs, BPS, and other sources related to this research. The results show that consumers do not have enough understanding about biofertilizer. XYZ fertilizer improves agricultural productivity but has some obstacles in its use. The business model of PT PHN is updated with some additions and subtractions by considering the CDM results.
\end{abstract}

Keywords: BMC, business model, CDM, strategy, customer discovery

\begin{abstract}
Abstrak: Kebutuhan terhadap produk pertanian di Indonesia semakin meningkat mengikuti tingginya pertumbuhan penduduk. Dengan terbatasnya lahan, produktivitas pertanian dapat ditingkatkan dengan penambahan pupuk. Pupuk hayati akhir-akhir ini terkenal sebagai solusi untuk peningkatan produktivitas pertanian pada lahan yang terbatas. PT PHN adalah perusahaan yang baru berdiri pada 2015 dan memproduksi pupuk hayati dengan merk XYZ. Penelitian ini dilaksanakan untuk menganalisis persepsi konsumen terhadap pupuk hayati dan pupuk XYZ. Perusahaan berusaha memahami permasalahan konsumen dan menyediakan solusi dengan metode customer development model (CDM). Pemahaman atas solusi tersebut kemudian digunakan sebagai bahan untuk merevisi model bisnis perusahaan dengan pendekatan business model canvas (BMC). Penelitian menggunakan data primer dan sekunder. Data primer diperoleh melalui observasi, wawancara dan pengisian kuesioner oleh beberapa responden. Data sekunder diperoleh dari data internal PT PHN, BPS, dan sumber lain terkait penelitian ini. Hasil penelitian menunjukkan bahwa konsumen tidak memiliki pemahaman yang cukup mengenai pupuk hayati. Pupuk XYZ terbukti meningkatkan produktivitas pertanian tetapi terdapat kesulitan dalam penggunaannya. Model bisnis PT PHN diperbarui dengan beberapa tambahan dan pengurangan dalam elemen sesuai dengan hasil CDM.
\end{abstract}

Kata kunci: BMC, model bisnis, CDM, strategi, customer discovery

\footnotetext{
${ }^{1}$ Corresponding author:

Email: marlin.yeni@gmail.com
} 


\section{INTRODUCTION}

Population of Indonesia grows every year in acceleration of $1.49 \%$ annually. According to the population census in 2010, Indonesia had 237,641,326 people (BPS, 2017). This increase will raise demand for food and agricultural products. Increase in agricultural land and productivity will be needed to fulfill food necessity. The increase of agricultural land is below the increase of food demand. On the other hand, land conversion from agricultural land into settlement also increases. Fertilizer becomes one of the solutions to increase agricultural productivity in limited land. Fertilizer is one of the growing industrial commodities in Indonesia. According to Fertilizer Enterpreneur Asscociation in Indonesia (APPI), request for fertilizer tends to increase and surpass the supply. BPS data shows that as much as $66,261,100$ tons of fertilizer was imported from 2007 to 2014.

The Ministry of Agriculture Decree Number 70/2011 defines organic fertilizer as fertilizer made from remnant of dead plants, animal dung, parts of animal and/or another organic waste which are processed in solid or liquid form. It can be enriched with mineral and/or microbe, which is useful to increase nutrient and organic matters and to repair the physical, chemical, and biological nature of the land. Biofertilizer, on the other hand, is an active biological product consisting of microbes that can increase fertilizing efficiency, fertility, and health of the land. Based on those definitions, it can be concluded that biofertilizer is a matter which can enrich the nutrient of organic fertilizer.

Nugraheni and Purnama (2013) explained that one of the biggest farmer's problems in early application of organic farming is low productivity. Biofertilizer in community usually known as organic fertilizer but eventually those two kinds of fertilizer have different use and composition. Biofertilizer is used along with the chemical or organic fertilizer to increase plant productivity. Biofertilizer can be regarded as a farmer solution to increase agricultural productivity in limited land by using eco-friendly fertilizer. Continuous use of chemical fertilizer will degrade the land and environment (Mishra et al. 2013). On the other hand, biofertilizer application has proven to increase productivity for tomato (Masfufah et al. 2015), cabbage (Iwantari et al. 2015), yellow corn (El-Mekser et al. 2016) and rice (Hartanto and Melati, 2013).

PT PHN is a new company established in 2015 and produce biofertilizer by the XYZ brand. Analysis to discover the right business model as a new company is needed by PT PHN. A company needs to understand customer's wishes and needs to give the right product which fit into the market. Understanding the customer's needs will affect the company's strategy. Suitable strategy for current company and market condition will be needed by PT PHN to grow and compete with another existing product. The purpose of this study is to analyze customer perceptions of biofertilizer and $\mathrm{XYZ}$ fertilizer and to formulate new business models and strategies to develop the XYZ fertilizer business. This research was conducted with customer discovery approach in customer development model (CDM) and business model canvas (BMC). Customer discovery is the first stage of customer development model that aims to find the right customer for the company. This stage is the most crucial stage to determine the future of a business.

Research with BMC approach was also conducted by Cidhy et al. (2016) to design business model prototype. Another application of BMC was also conducted by using BMC and SWOT (Yuliasih and Aisyah, 2015; Permadi et al. 2016) and BMC, SWOT, and Blue Ocean (Chandra, 2016). Dudin et al. (2015a) stated that BMC is a good tool for detailed utilization including financial management while in another research, Dudin et al. (2015b) claimed that BMC is an effective management tool. BMC is also reliable to deal with an uncertain situation (Andries et al. 2013). The relevance of previous research with this research is that BMC is used to build and update the company's business model.

Chanin et al. (2017) conducted a research on CDM implementation in startup incubation program. The conclusion from that research is that CDM helps startup to understand the challenges. Knowing who the customers are and what problems they want to solve is the initial task of startup. Lipusch et al. (2017) conducted research with the aim to analyze the literature related to startup development involving customers, in relation to customer development and lean startup. Lipusch et al. (2017) concluded that research in scientific literature in relation to CDM and lean startup was done separately. Holistic research is still not a scientific concern. The relevance of previous research with this research is the method used. This study only uses the customer discovery step of all stages contained in the CDM to analyze customer problems from PT PHN including the new company. 
The scope of analysis and discussion in this study consist of a general description of PT PHN, analysis of customer wishes and problems with customer discovery stage approach in customer development model, and it compiles a new business model with business model canvas approach which can be then recommended for biofertilizer business of PT PHN.

\section{METHODS}

Primary and secondary data were gathered from information and data related to the research. Primary data were obtained from observation, interview, and questionnaire. Interview was conducted to PT PHN's decision makers for XYZ selling. Questionnaires were supposed to be distributed to all 19 people of XYZ customers, but only 10 people were able to make it. Secondary data were obtained from internal company's data, BPS, and other sources related to the research. Research was held in marketing trial area of XYZ fertilizer in Pangalengan, Bandung in April-May 2017. Data were then analyzed using customer development model (CDM) and business model canvas (BMC) methods. The findings of understanding the customer's problems and solution were analyzed using customer discovery stage of CDM. CDM is a model developed by Blank and Dorf (2015) to access the detail of activities related to the customer from start-up early stage until it is processed to become a company, which is designed in four easy steps. The first step is pouring the vision of the company founders into the business model. The second step is testing the product in the field. The third step is testing the solution of the existing problems regarding the company's products with the customers. The results of the second and third steps are then used to update the company's business model. The fourth step is the final step in the customer discovery stage. In this step the company must verify product features, business models and financial analysis to decide on pivot or to proceed. Financial analysis is done by entering data of production cost, acquisition cost, operational cost and income so that it will be followed-up by the company fund at the end of the quarter. This fund will be a consideration for the company to decide on pivot or to proceed.

A new business model is then created based on customer discovery analysis. The business model can be easily configured and redesigned (Tsai et al. 2011). The business model can also be utilized to arrange a business strategy formulation (Priandita and Toha, 2013). PT PHN new business model is arranged with BMC approach. Osterwalder and Pigneur (2012) in their book, Business Model Generations, mention that a business model canvas is a language to describe, visualize, assess, and convert business model. BMC is mapped into nine building blocks or connected elements (Wandebori, 2012).

Farmers use fertilizer to increase the agricultural productivity to meet the growing demand for agricultural products. Environmental issues and healthy living trends increase the demand for organic agricultural products. Biofertilizer is an eco-friendly fertilizer that can improve agricultural productivity. PT PHN's biofertilizer demand continues to decrease. In this study, researchers analyzed customer perceptions of PT PHN on biofertilizer and XYZ fertilizer. The researchers also analyzed the problems and desires of the customers on XYZ fertilizer using the customer discovery stages which would then result in a new business model with a BMC approach and a strategy for PT PHN. Framework for this research is visualized in Figure 1.

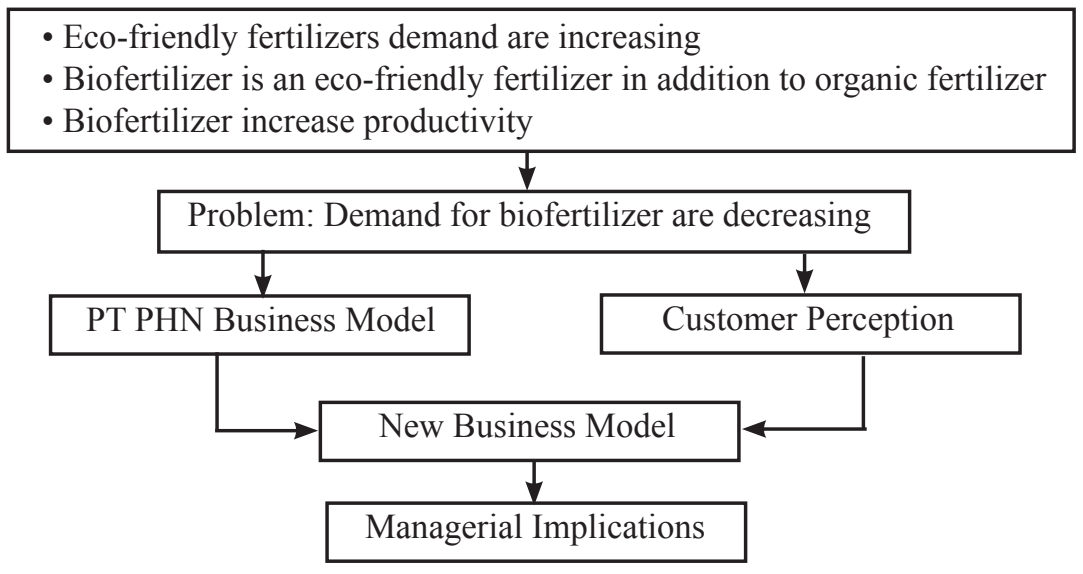

Figure 1. Research framework 


\section{RESULTS}

\section{Customer PT PHN Perception of Biofertilizer and XYZ Fertilizer}

Perception of biofertilizer

As many as 8 out of 10 respondents admit that they know about biofertilizer. Respondents know that there are three kinds of fertilizer, i.e. organic, chemical, and biofertilizer. From a deeper interview, it turns out that only 2 of the 10 respondents who understand the differences between biofertilizer and organic fertilizer. Biofertilizer evidently is often considered to be similar with organic fertilizer because both fertilizers are equally environmentally friendly. Farmers often assume that biofertilizer is just another name of organic fertilizer. The differences of organic fertilizer and biofertilizer are the composition and benefit

\section{Perception of XYZ fertilizer}

Table 1 shows respondents' perceptions of XYZ fertilizer. Respondents get their XYZ fertilizer directly from PT PHN's factory in Pangalengan. Respondents who live quite far from the factory find it difficult to get this fertilizer.

The tag price of XYZ fertilizer according to respondents is quite appropriate with its benefit and is not so different from another biofertilizer they usually use. $X Y Z$ fertilizer offers value propotitions that by using XYZ fertilizer combined with organic or chemical fertilizer will raise crop production by $30 \%$ and reduce chemical fertilizer use by $50 \%$. As much as $90 \%$ of respondents agree that XYZ fertilizer increases crop production, but only $60 \%$ of the respondents still use $\mathrm{XYZ}$ fertilizer. One of the reasons is because of the difficulty of applying this fertilizer. As much as $90 \%$ respondents admit to have difficulty to apply $\mathrm{XYZ}$ fertilizer. This difficulty is related to the origin of this XYZ fertilizer which cannot be used simultaneously with pesticide. Respondents usually apply fertilizer in conjunction with pesticide to save time and energy. This biofertilizer contains active microbes which cannot be exposed to pesticide which can easily kill them.

\section{First Stage Customer Discovery}

Vision and market size

Vision of $\mathrm{XYZ}$ fertilizer produced by PT PHN is to increase agricultural productivity by combining biofertilizer with organic or chemical fertilizer which is more environmentally friendly. The advantage of $\mathrm{XYZ}$ fertilizer is to increase crop productivity. XYZ fertilizer which is combined with chemical fertilizer will reduce the use of chemical fertilizer. Biofertilizer is environmentally friendly fertilizer so that using $\mathrm{XYZ}$ fertilizer will slowly restore land's health and fertility.

XYZ fertilizer produced by PT PHN is a typically new product for farmers. In customer disocery process, PT PHN needs people which deliberately want to use and buy XYZ fertilizer. This early customer then become PT PHN's earlyvangelist. They are farmers who are willing to take the risk to use and buy an early product of XYZ fertilizer and change their behavior of using fertilizer. There are 6 farmers that become earlyvangelist of XYZ fertilizer.

In the first stage of customer discovery, company have to develop rough estimation of market size to measure the opportunity for the newly established company. According to the data from APPI, fertilizer demand tends to increase and surpass the supply. The Total Available Market (TAM) for XYZ fertilizer is farmers who want to increase agricultural productivity without further damage to the environment (by using environmentally friendly fertilizer). The Serviceable Available Market (SAM) is farmers inside PT PHN's area of distribution. The target market is seeds, tubers, vegetables, and fruits farmer located in Lampung, West Java, Central Java, and East Java.

Table 1. Customer perception of XYZ fertilizer

\begin{tabular}{ll}
\hline \multicolumn{2}{c}{ Customer perception of XYZ fertilizer } \\
\hline The ease of obtaining XYZ fertilizer & $80 \%$ Easy \\
Pricing of XYZ fertilizer & $70 \%$ Suitable \\
Ease of use of XYZ fertilizer & $10 \%$ Easy \\
Crop productivity effect of XYZ & $90 \%$ Positive \\
fertilizer & \\
Chemical fertilizer reduction effect of & $70 \%$ Positive \\
XYZ fertilizer & \\
Currently using XYZ fertilizer & $60 \%$ Using \\
\hline
\end{tabular}


In order to sell $\mathrm{XYZ}$ fertilizer, the company can hire manpower to directly sell product to end user or by reseller. Direct selling has a great control and supervision and dedicated selling force, but usually hard to achieve good results because a talented selling force is hard to find. Selling by distributor/reseller can be an option so that the sale can reach a lot of wider area far from the factory.

Customer is the most important thing because a company will never exist if there are no customers. Customer relationship is a strategy and tactic to get, keep, and grow customer. PT PHN can conduct the customer stage by two options, free and paid media. Table 2 shows the strategy to get, keep, and grow PT PHN's customers.

\section{Key resources}

PT PHN has to possess several key resources to support company activities. Key resources are classified into four main categories, that are physical, financial, human, and intellectual. PT PHN's physical resources are one office, one factory, seven stainless steel pump machines, three water filters, ten tanks with 1,000 liter capacity. Financial resources come from the company owner to run business activities. PT PHN possess several human resources, that is one doctoral degree director helped by four managers.
As for the intellectual resources PT PHN have two patents, that is patent for liquid biofertilizer for all crops and plantations including its method of manufacture and patent for solid biofertilizer composition which contains animal dung, mycorrhiza, trichoderma, decomposer, including its method of manufacture.

\section{Key partners}

Companies need an important partner that provides capabilities, products, or services that they can't or don't want to develop themselves. PT PHN can build strategic alliances with other companies that do not compete with PT PHN. PT PHN can build an alliance with PT THN which is a subsidiary of PT OPQ. PT THN is a company that produces herbal booster for animals that are useful for pets or livestock. Production of PT PHN's biofertilizer requires some materials not provided by the company so that the company must build relationships with suppliers. Suppliers can be part of the company's success.

A strong and flexible partnership between the company and its suppliers is critical to the company's success. Bacteria are the most important ingredients in the manufacture of biofertilizers. Table 3 shows partners of PT PHN in the business.

Table 2. Strategy to get, keep, and grow customer

\begin{tabular}{|c|c|c|}
\hline Get & Keep & Grow \\
\hline $\begin{array}{l}\text { Free media } \\
\text { - } \begin{array}{l}\text { Distributing leaflets addressed to } \\
\text { farmers }\end{array} \\
\text { - } \begin{array}{l}\text { Create a letter of offer to potential } \\
\text { business partners }\end{array} \\
\text { Paid media } \\
\text { - Use third-party educators to } \\
\text { educate the market while selling } \\
\text { products } \\
\text { Use seminars related to the use of } \\
\text { biofertilizers } \\
\text { Build pilot demonstration plot } \\
\text { - } \begin{array}{l}\text { Promotion through commonly used } \\
\text { media such as local radio }\end{array} \\
\text { Provision of product samples to } \\
\text { farmers }\end{array}$ & $\begin{array}{l}\text { - Maintain nodes or recommenders } \\
\text { with a personal approach } \\
\text { - } \quad \text { Conducting discussion and } \\
\text { feedback session with farmer } \\
\text { groups } \\
\text { - } \quad \text { Promotion through the common } \\
\text { media used by farmers such as } \\
\text { subscription discount programs and } \\
\text { training if subscribed } \\
\text { - Maintain and improve service } \\
\text { quality }\end{array}$ & 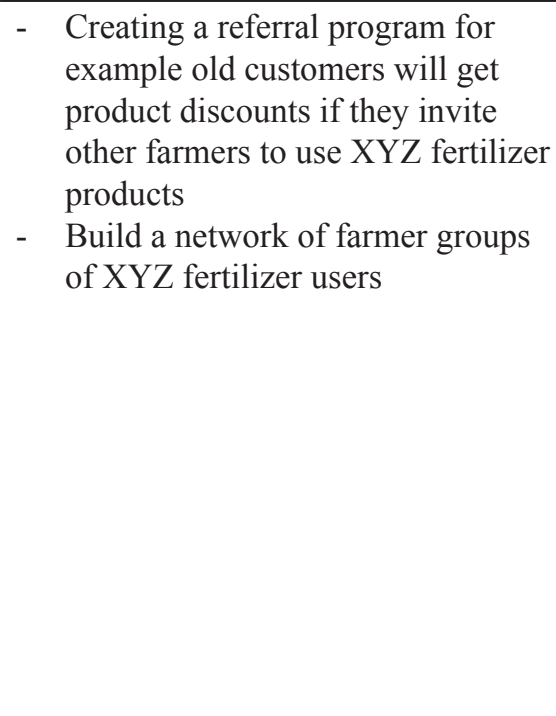 \\
\hline
\end{tabular}




\begin{tabular}{lll}
\hline \multicolumn{1}{c}{ Partners } & \multicolumn{1}{c}{ Partner Provide } & \multicolumn{1}{c}{ PT PHN Provide } \\
\hline PT THN & Network & Network \\
Lab. Mikrobiologi IPB & Bacteria propagation service & Money \\
KPBS & Molases, pure milk & Membership, money \\
Cow farmer & Pure milk & Money \\
Rabbit farmer & Rabbit urine & Money \\
Coconut farmer & Coconut water, coconut coir & Money \\
Watermelon farmer & Watermelon & Money \\
Pineapple farmer & Pineapple & Money \\
Bottle company & Bottle & Money \\
\hline
\end{tabular}

\section{Price}

Pricing is the most difficult thing to decide for a company. Before setting a price, the company must make an income report to ensure that the business model to be executed makes financial sense. PT PHN has a target to sell XYZ fertilizer to Lampung, West Java, Central Java and East Java areas. Based on the internal data of PT PHN, it is known that the fertilizer needed per year for four provinces is as much as $36,838,757$ liters. The market share target of PT PHN is $0.2 \%$ of the total monthly fertilizer requirement in the four provinces of 73,678 liters per year or 6,139 liters per month. During the introduction and education period, XYZ fertilizer is sold at Rp35,000 per liter. This price is taken based on the consideration of production cost and price of organic fertilizer and chemical fertilizer which is widely used in the test area. Khorniawati (2014) stated that the price factor becomes one of the obstacles of most customers not to buy organic agricultural products and prefer non-organic products. Therefore, PT PHN's decision for pricing determination of XYZ fertilizer by considering fertilizer which is commonly used by farmers is the right step.

\section{BMC's first stage}

First stage of customer discovery is completed on the pricing of XYZ fertilizer product. Furthermore, the business model canvas is based on the first stage customer discovery of PT PHN's biofertilizer. Figure 2 shows the BMC's first stage customer discovery.

\section{Second Stage Customer Discovery}

In the second stage, PT PHN starts testing XYZ fertilizer products in the field. Testing of XYZ fertilizer products is done in the area around PT PHN factory located in Pangalengan, Bandung Regency, West Java. Tests are conducted by providing education to farmers. Education is provided by two educators. PT PHN provides free XYZ fertilizer to farmers given education. Each farmer gets one bottle containing one liter of XYZ fertilizer. Table 4 shows the implementation of education conducted by PT PHN.

PT PHN uses a demonstration plot (demplot) on four farmers' lands. Premium fertilizer that is XYZ fertilizer combined with cow dung and dirt worms is given to chinese cabbage and japanese spinach that will then be compared with the plants given chicken manure. Table 5 shows increased productivity and increased income of farmers using combined fertilizers. Crops are given a combination of chemical fertilizers and biofertilizers. Using this combined fertilizer, farmers can reduce 50\% of the use of chemical fertilizers and save $19.14 \%$ of the usual fertilizer spending.

PT PHN approaches customers by holding an event filled with a shared meal activity. In the event, some customers complain about the complexity of using $\mathrm{XYZ}$ fertilizer. Applying XYZ fertilizer is different from usual fertilizer they used.

The effectiveness of biofertilizers application is different in various types of plants. Based on Table 5, productivity of chinese cabbage increased by $48.40 \%$, Japanese spinach increased by $23.96 \%$ but potato productivity only increased by $2.87 \%$.

This difference in productivity increase makes farmers hesitant to use XYZ fertilizer for fear that the increased productivity is not proportional to the increase in expenditure due to the use of XYZ fertilizer. 


\begin{tabular}{|c|c|c|c|c|}
\hline \multirow[t]{2}{*}{$\begin{array}{l}\text { Key Partnership } \\
\text { - Supplier } \\
\text { - Distributor } \\
\text { - Farmer/Farmers group } \\
\text { - Cooperation }\end{array}$} & $\begin{array}{l}\text { Key Activities } \\
\text { - Production } \\
\text { - Distribution } \\
\text { - Education } \\
\text { - Marketing }\end{array}$ & \multirow{2}{*}{$\begin{array}{l}\text { Value Proposition } \\
\text { - Increasing crop } \\
\text { yield up top } 30 \% \\
\text { - Reducing chemical } \\
\text { fertilizer use up to } \\
50 \% \\
\text { - Does not harm the } \\
\text { soil }\end{array}$} & $\begin{array}{l}\text { Customer Relationship } \\
\text { Education of the use of } \\
\text { biofertilizer, agricultural } \\
\text { knowledge in general, } \\
\text { knowledge of chemical } \\
\text { fertilizer use }\end{array}$ & \multirow[t]{2}{*}{$\begin{array}{l}\text { Customer Segment } \\
\text { Seeds, tubers, vegeta- } \\
\text { bles, and fruits farmer } \\
\text { located in Lampung, } \\
\text { West Java, Central } \\
\text { Java, and East Java }\end{array}$} \\
\hline & $\begin{array}{l}\text { Key Resources } \\
\text { - Researcher } \\
\text { - Patent } \\
\text { - Agent } \\
\text { - Educator } \\
\text { - Staff } \\
\text { - Capital } \\
\end{array}$ & & $\begin{array}{l}\quad \text { Channels } \\
\text { - Distributor } \\
\text { - Cooperation/Farmers } \\
\text { group } \\
\text { - Online marketplace }\end{array}$ & \\
\hline \multicolumn{2}{|c|}{$\begin{array}{l}\text { Cost Structure } \\
\text { - Marketing, administration, distribution cost } \\
\text { - Raw material } \\
\text { - Machinary } \\
\text { - Building }\end{array}$} & \multicolumn{3}{|c|}{$\begin{array}{l}\text { Revenue Stream } \\
\text { - Selling XYZ through distributor/reseller } \\
\text { - Selling XYZ through cooperation/farmers group } \\
\text { - Selling through online channel }\end{array}$} \\
\hline
\end{tabular}

Figure 2. BMC PT PHN's first stage

Table 4. Education program from PT PHN

\begin{tabular}{ll}
\hline \multicolumn{1}{c}{ Item } & \\
\hline Attendant target & 300 farmers \\
Locations & 15 villages (Los Cimaung, Datar, Babakan Kiara, Pasir malang, Lospadung, Kebon Kai, Cilaki, \\
& Lebak Saat, Wates, Pulosari, Cibereum Pejaten, Neglasari, Cikolotok, Loskulalet, dan Cisangkuy) \\
Time & August - November 2015 \\
Education technique & - Presentation on farmer's habits vs. proper cultivation techniques (seed selection, fertilizer use \\
& rules, pesticide use rules) \\
& - Presentation on biofertilizer \\
Education target & - Understanding 3R (right on target, right on dose, right on time) in fertilizer or pesticide \\
& application \\
Impact & - Farmers are more sensitive to the use of chemicals and their impact on the environment \\
& - Repurchase by 6 farmers \\
& - Total purchase 92 liters for 4 months \\
\hline
\end{tabular}

Table 5. Result of combined XYZ fertilizer demplot test

\begin{tabular}{lcc}
\hline \multicolumn{1}{c}{ Commodity } & $\begin{array}{c}\text { Productivity } \\
\text { increasing }\end{array}$ & $\begin{array}{c}\text { Earnings } \\
\text { increasing }\end{array}$ \\
\hline Chinese cabbage & $48.40 \%$ & $29.45 \%$ \\
Potato & $2.87 \%$ & $1.74 \%$ \\
Japanese spinach & $23.96 \%$ & $22.14 \%$ \\
\hline
\end{tabular}

\section{Third Stage Customer Discovery}

With a deeper understanding of their customers and their problems, it is time for an important stage in the customer development process, that is pivot or proceed.
This phase begins with an update of the business model and team of PT PHN. BMC of PT PHN after the update can be seen in Figure 3.

After a business model is updated, the company must test the solution of the existing problems regarding XYZ fertilizer with customers. Based on the results of a direct discussion with some XYZ fertilizer customers, it has been known that they are interested to use XYZ fertilizer because of the benefits provided by the fertilizer. Customers still complain that the use of XYZ fertilizer is not practical. Aprianti et al. (2015) research in Bogor Regency shows that majority of farmers never use biofertilizer because of its difficulty. 


\begin{tabular}{|c|c|c|c|c|}
\hline \multirow[t]{2}{*}{\begin{tabular}{l} 
Key Partnership \\
\multicolumn{1}{c}{ - Supplier } \\
- Distributor \\
- Farmer/Farmers group \\
- Cooperation
\end{tabular}} & $\begin{array}{l}\text { Key Activities } \\
\\
\text { - Production } \\
\text { - Distribution } \\
\text { - Education } \\
\text { - Marketing }\end{array}$ & \multirow[t]{2}{*}{$\begin{array}{l}\text { Value Proposition } \\
\\
\text { - Increasing crop } \\
\text { yield up top } 30 \% \\
\text { - Reducing chemical } \\
\text { fertilizer use up to } \\
50 \% \\
\text { - Does not harm the } \\
\text { soil }\end{array}$} & $\begin{array}{l}\text { Customer Relationship } \\
\text { Periodic education of } \\
\text { the use of biofertilizer, } \\
\text { agricultural knowledge } \\
\text { in general, knowledge of } \\
\text { chemical fertilizer use }\end{array}$ & \multirow[t]{2}{*}{\begin{tabular}{|l} 
Customer Segment \\
Seeds, tubers, \\
vegetables, and fruits \\
farmer located in \\
Lampung, West Java, \\
Central Java, and East \\
Java
\end{tabular}} \\
\hline & $\begin{array}{l}\text { Key Resources } \\
\\
\text { - Researcher } \\
\text { - Patent } \\
\text { - Agent } \\
\text { - Educator } \\
\text { - Staff } \\
\text { - Capital }\end{array}$ & & $\begin{array}{l}\text { Channels } \\
\text { - Distributor } \\
\text { - Cooperation/Farmers } \\
\text { group } \\
\text { - Online marketplace }\end{array}$ & \\
\hline \multicolumn{2}{|c|}{$\begin{array}{l}\text { Cost Structure } \\
\text { - Marketing, administration, distribution cost } \\
\text { - Raw material } \\
\text { - Machinary } \\
\text { - Building }\end{array}$} & \multicolumn{3}{|c|}{$\begin{array}{l}\text { Revenue Stream } \\
\text { - Selling XYZ through distributor/reseller } \\
\text { - Selling XYZ through cooperation/farmers group } \\
\text { - Selling through online channel }\end{array}$} \\
\hline
\end{tabular}

Figure 3. Second stage BMC of PT PHN

$\mathrm{XYZ}$ fertilizer can not be used in conjunction with pesticides because the biofertilizer contains active microbes. Farmers in Pangalengan used to apply chemical fertilizers or organic fertilizers together with pesticides to save time and energy. Application of XYZ fertilizer also requires sterile container so it is rather difficult for farmers because they have to sterilize first the container to be used.

There is one customer who has no problem regarding the use of XYZ fertilizer. He uses a plastic trashbag to coat the inside of the container to be used for the fertilizer so that the container can be used directly without having to wash the container first. The use of trashbag can be used as a solution in the use of XYZ fertilizer that requires a sterile container. The company can sell XYZ fertilizers equipped with trashbag in one package to facilitate farmers in the use of XYZ fertilizer. The Company may also provide guidance on the use of XYZ fertilizers on a single sheet of paper in XYZ fertilizer packaging.

Constraints on the use of XYZ fertilizers that can not be used together with pesticides will not appear if $\mathrm{XYZ}$ fertilizer is used by organic farmers. B2B organic farming raised in the channel section of BMC PT PHN in order for the company to make cooperation of XYZ fertilizer sales to organic farmers. Organic farmers do not use pesticides in their agricultural activities so that XYZ fertilizer can be easily used by organic farmers.
Most XYZ fertilizer customers want to be given regular education and assistance on the use of biofertilizers and agricultural knowledge. Lots of customers of XYZ fertilizer still lack of comprehensive understanding about biofertilizer and the difference between biofertilizer and organic fertilizer. Companies can hold meetings with customers that are packaged in an interesting way on a regular basis. In the event, the company can provide education to customers. The company can also dig up customer's opinion information about XYZ fertilizer in the event. Information will be very useful for the development of PT PHN products. Education to customers can also be provided through newsletters created by the company.

The use of XYZ fertilizer combined with organic fertilizer or chemical fertilizer has a positive impact on the plant. Increased productivity of plants that use a combination of biofertilizer varies on each type of plant. Increased revenue from the sale also differed on each type of plant and depending on the current market price. PT PHN must inform customers of the difference in productivity increases in each type of plant. PT PHN can use bulletins distributed to customers to inform productivity improvement of each plant. Providing a simulation of the cost calculations is required when using $\mathrm{XYZ}$ fertilizer and how much increase in productivity and income. Figure 4 shows the PT PHN business model in the third stage of the costumer discovery. 


\section{Fourth Stage Customer Discovery}

This stage begins with verification of product and market suitability. After that, customers and how to reach them need to be verified, to find out whether the company can make money which will ultimately decide the pivot or proceed. PT PHN provides education to 300 farmers in the Pangalengan area which has a total land of about 150 hectares. According to calculations performed by the internal company, with the selling price of fertilizer XYZ Rp35,000 per liter there is 1.6\% of biofertilizer purchases from the total target market of 6,000 liters during the educational period. Repurchase the XYZ fertilizer by farmers because XYZ fertilizer can solve farmers' problems on how to increase the producvity associated with the increasing demand for agricultural products while agricultural land does not increase significantly.

\section{Managerial Implication}

With the strategy implemented by the company and from the results of financial analysis of biological fertilizer (Table 6), it is seen that the business undertaken by PT PHN is currently not prospective. Since launching $\mathrm{XYZ}$ fertilizer products, PT PHN is constrained by distribution permit when it will offer and sell products to the target market. The complicated and time-consuming process of distribution permit makes PT PHN unable to execute a strategy to sell XYZ fertilizer including a very important promotion for new products.

There is no sufficient income to cover the operational expenses of the company existing. PT PHN can still continue its business in the field of biofertilizer by changing the strategy which is currently used. When testing XYZ fertilizer to customer, it is discovered that there are $1.6 \%$ of customers who repurchase. With the new distribution permit obtained by the company, PT PHN can re-test their market penetration.

\begin{tabular}{|c|c|c|c|c|}
\hline \multirow[t]{2}{*}{$\begin{array}{l}\quad \text { Key Partnership } \\
\text { - Supplier } \\
\text { - Distributor } \\
\text { - Farmer/Farmers group } \\
\text { - Cooperation }\end{array}$} & $\begin{array}{l}\text { Key Activities } \\
\\
\text { - Production } \\
\text { - Distribution } \\
\text { - Education } \\
\text { - Marketing }\end{array}$ & \multirow[t]{2}{*}{$\begin{array}{l}\text { Value Proposition } \\
\\
\text { - Increasing crop } \\
\text { yield up top } 30 \% \\
\text { - Reducing chemical } \\
\text { fertilizer use up to } \\
50 \% \\
\text { - Does not harm the } \\
\text { soil }\end{array}$} & $\begin{array}{l}\text { Customer Relationship } \\
\text { Periodic education of } \\
\text { the use of biofertilizer, } \\
\text { agricultural knowledge } \\
\text { in general, knowledge of } \\
\text { chemical fertilizer use }\end{array}$ & \multirow[t]{2}{*}{$\begin{array}{l}\text { Customer Segment } \\
\text { Seeds, tubers, } \\
\text { vegetables, and fruits } \\
\text { farmer located in } \\
\text { Lampung, West Java, } \\
\text { Central Java, and East } \\
\text { Java }\end{array}$} \\
\hline & $\begin{array}{l}\text { Key Resources } \\
\\
\text { - Researcher } \\
\text { - Patent } \\
\text { - Agent } \\
\text { - Educator } \\
\text { - Staff } \\
\text { - Capital }\end{array}$ & & 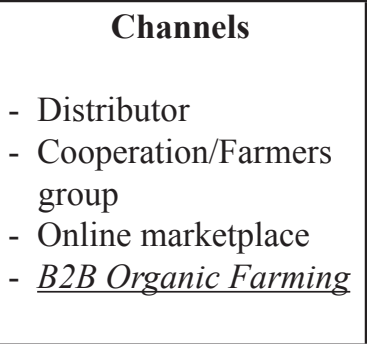 & \\
\hline \multicolumn{2}{|c|}{$\begin{array}{l}\text { Cost Structure } \\
\text { - Marketing, administration, distribution cost } \\
\text { - Raw material } \\
\text { - Machinary } \\
\text { - Building }\end{array}$} & \multicolumn{3}{|c|}{$\begin{array}{l}\text { Revenue Stream } \\
\text { - Selling XYZ through distributor/reseller } \\
\text { - Selling XYZ through cooperation/farmers group } \\
\text { - Selling through online channel } \\
\text { - Selling from cooperation with organic farming }\end{array}$} \\
\hline
\end{tabular}

Figure 4. Third stage BMC of PT PHN's

Table 6. Financial analysis PT PHN (in Rupiah)

\begin{tabular}{|c|c|c|c|c|}
\hline Category & Q1 & Q2 & Q3 & Total \\
\hline Income & $3,290,000$ & $20,965,000$ & $2,975,000$ & $27,230,000$ \\
\hline Production cost & $10,240,000$ & $10,240,000$ & & $20,480,000$ \\
\hline Acquisition cost & $13,021,000$ & & & $13,021,000$ \\
\hline Operational cost & $68,000,000$ & $68,000,000$ & $68,000,000$ & $204,000,000$ \\
\hline Total expense & $91,261,000$ & $78,240,000$ & $68,000,000$ & $237,501,000$ \\
\hline Funds in end of quartal & $-87,971,000$ & $-57,275,000$ & $-65,025,000$ & \\
\hline
\end{tabular}


Companies must possess human resources separated from PT THN human resources.Separation of human resources has to be done so that workers can stay focused at work and do it optimally. PT PHN can reduce expenses by reducing operational costs and acquisition costs. Pricing of XYZ fertilizer should be done with consideration from the cost of production and price of competitors at this time.

Before producing large quantities of XYZ fertilizer and planning to sell XYZ fertilizer more widely, PT PHN must conduct customer discovery process using the latest business model. The previous test process was only done in Pangalengan area, so after the distribution permit of XYZ fertilizer came out, the company could conduct trials with a larger area. By running a customer discovery process, PT PHN can measure a viable and profitable business model and measure how big the $\mathrm{XYZ}$ fertilizer market is before deciding to make a sale.

\section{CONCLUSIONS AND RECOMMENDATIONS}

\section{Conclusions}

The majority of consumers know about biofertilizers but do not understand the difference between biofertilizer and organic fertilizer. The majority of consumers receive $\mathrm{XYZ}$ fertilizers as a solution to their problems of increasing productivity with limited land. Consumers agree that the use of XYZ fertilizers may reduce the use of chemical fertilizers. The business model of PT PHN is updated with some additions and subtractions.

Companies should conduct customer discovery processes with new business models with larger areas before making large sales. Companies must have separate human resources from PT THN HR so that workers can stay more focused at work and do it optimally.

\section{Recommendations}

Basically PT PHN has a good value proposition, proved from the test of effectiveness and acceptance of products by customers. However, in order to run the biofertilizer business, PT PHN must change its strategy, test consumers again and adjust the business model according to the test result to the consumers.

\section{REFERENCES}

Andries P, Debackere K, Looy BV. 2013. Simultaneous experimentation as a learning strategy: business model development under uncertainty. Strategic Entrepreneurship Journal 7: 288-310. https:// doi.org/10.1002/sej.1170.

Aprianti E, Suharjo B, Muflikhati I. 2015. Positioning pupuk hayati (Studi kasus PT. Karya Anugrah Rumpin). Jurnal Manajemen dan Agribisnis 12(2): 106-114.

Blank S, Dorf B. 2015. The Starup Owner's Manual Panduan Langkah Demi Langkah untuk Membangun Sebuah Perusahaan Hebat. Ervan $\mathrm{J}$, penerjemah. Indonesia: PT Elex Media Komputindo. Terjemahan dari The Startup Owner's Manual The Step by Step Guide for Building a Great Company.

[BPS] Badan Pusat Statistik. 2017. Impor pupuk menurut negara asal utama 2000-2014. https:// www.bps.go.id/linkTabelStatis/view/id/1044 [11 February 2017].

[BPS] Badan Pusat Statistik. 2017. Jumlah dan distribusi penduduk. http://sp2010.bps.go.id/ index.php/site/topik?kid=1\&kategori=Jumlahdan-Distribusi-Penduduk [7 April 2017].

Chandra D. 2016. Model bisnis pada perusahaan X menggunakan business model canvas. AGORA 4(1): 18-25.

Chanin R,Pompermaier L, Fraga K, SalesA, Prikladnicki R. 2017. Applying customer development for software requirements in a startup development program. In: The 1st International Workshop on Software Engineering for Startups. Buenos Aires, 20-28 May 2017. New Jersey: IEEE Press. https://doi.org/10.1109/SoftStart.2017.3.

Cidhy DATK, Baga LM, Djohar S. 2016. Pariwisata kreatif dan kegiatan ekstrakulikuler berbasis bambu dalam pengembangan model bisnis CV Suratin Bamboo. Jurnal Manajemen dan Aribisnis 13(3): 22-239.

Dudin MN, Kutsuri GN, Fedorova IJ, Dzusova SS, Namitulina AZ. 2015a. The innovative business model canvas in the system of effective budgeting. Asian Social Science 11(7): 290-296. https://doi.org/10.5539/ass.v11n7p290.

Dudin MN, Lyasnikov NV, Leont'eva LS, Reshetov KJ, Sidorenko VN. 2015b. Business model canvas as a basis for the competitive advantage of enterprise structures in the industrial agriculture. Biosciences Biotechnology Research Asia 12(1): 
887-894. https://doi.org/10.13005/bbra/1736.

El-Mekser HKhA, Mohamed ZEM, Elsayed WM. 2016.

Yellow corn productivity and quality under using different minerals and biofertilizer rates. Journal of Agri-Food and Applied Sciences 4(3): 60-72.

Hartanto M, Melati M. 2013. Budidaya padi organik dengan waktu aplikasi pupuk kandang yang berbeda dan pemberian pupuk hayati. Buletin Agrohorti 1(4): 9-17. https://doi.org/10.29244/ agrob.1.4.9-17.

Iwantari A, Supriyanto A, Nurhariyati T. 2015. Pengaruh pemberian biofertilizer dan jenis media tanam terhadap pertumbuhan dan produktivitas tanaman kubis (Brassica oleracea). Jurnal Ilmiah Biologi 3(1): 85-94.

Khorniawati M. 2014. Produk pertanian organik di Indonesia: Tinjauan atas peferensi konsumen Indonesia terhadap produk pertanian organik lokal. Jurnal Studi Manajemen 8(2): 171-182

Lipusch N, Ebel P, Dellermann D, Bretscneider U. 2017. Customer feedback for startups a process model and research agenda. In: The 2017 ISPIM Innovation Conference. Vienna, 18-22 June 2017. Lappeenranta: LUT Scientific and Expertise Publications Reports.

Masfufah A, Supriyanto A, Surtiningsih T. 2015. Pengaruh pemberian pupuk hayati (biofertilizer) pada berbagai dosis pupuk dan media tanam yang berbeda terhadap pertumbuhan dan produktivitas tanaman tomat (Lycopersicon esculentum) pada polybag. Jurnal Ilmiah Biologi 3(1): 1-11.
Mishra N, Hussain M, Khan SF, Masmali F. 2013. Promotional strategy for biofertilizer in Tarai region of State Uttara Khand, India. International Journal of emerging Ressearch in Management and Technology 1(2): 38-45.

Nugraheni S, Purnama AFD. 2013. Problems and prospect of organic farming in Indonesia: lesson from five districts in West ava Province. Majalah Ilmiah Bina Ekonomi 1(1): 112-120.

Osterwalder A, Pigneur Y. 2012. Business Model Generation (terjemahan). Jakarta: PT Elex Media Komputindo.

Permadi B, Nurmalina R, Kirbrandoko. 2016. Analisis pengembangan model bisnis kanvas CV Kendura Keramik Bandung. Jurnal Aplikasi Manajemen 14(1):88-97.https://doi.org/10.18202/ jam23026332.14.1.10.

Priandita A, Toha M. 2013. Business strategy formulation using business model case study: PT Kartia Tri Satria. The Indonesian Journal of Business Administration 2 (1):68-75.

Tsai HM, Lin YD, Su YH. 2011. A grounded theory on the business model structure of google. Journal Business Management 9(3): 231-242.

Wandebori M. 2012. Business model generation of majalah Epik. Journal of Business and Management 1(5): 365-369.

Yuliasih I, Aisyah N. 2015. Pengembangan model bisnis manisan cabai merah (Capsicum annum). E-Jurnal Agroindustri Indonesia 4(1): 214-221. 